\title{
MONUMENTALITY IN THE MEKONG DELTA: LUMINESCENCE DATING AND IMPLICATIONS
}

\author{
M. T. Stark*, D. Sanderson**, R. G. Bingham** \\ *University of Hawai'i-Manoa, 2500 Campus Road, Hawai'i, Hall 202, Honolulu, HI 96822 \\ **Scottish Universities Environmental Research Centre, Rankine Avenue, Scottish Enterprise Technology Park, \\ East Kilbride, G75 0QF, Scotland, UK
}

\begin{abstract}
Brick monuments are one hallmark of emergent political complexity across much of mainland Southeast Asia during the first millennium AD. They first appeared in association with Indic statuary, large nucleated settlements, and the region's earliest states. Chronometric research in the Mekong delta on the earthen and brick wall that surrounds Angkor Borei (southern Cambodia) provides some of the earliest secure dates for brick architecture in the region. This paper presents preliminary results of the dating program at Angkor Borei and examines the utility of luminescence techniques for dating historic period monuments across mainland Southeast Asia.
\end{abstract}

Being Earth and the Word, the brick is a goddess: 'To thee, O Goddess, Brick, let us sacrifice with oblation' (Kramrisch 1976:105)

Brick construction technology appeared throughout much of mainland Southeast Asia by the mid-first millennium $\mathrm{AD}$, and is associated with the earliest states in the region. Populations in these early states used bricks to construct encircling settlement walls, to erect religious structures for housing Indic deities (Parmentier 1932:187), to create Buddhist caitya or stupa shrines within and around their settlements, and to construct mortuary monuments that contained cremations. Given the large number of brick monuments in India and Southeast Asia, the cultural significance of the monuments themselves and their spread through the region and the difficulties of obtaining absolute ages for the bricks and brick structures using other means, a huge need exists to date bricks directly that were used in these public works.

This article focuses on dating bricks used to construct first millennium AD monuments, shrines, and other public works. Several persistent questions concerning the earliest brick technology remain unanswered, including the range of construction uses, the linkage between this technology and other concomitant organizational shifts, and the origins of this particular technology. None of these questions can be answered, however, without a solid grasp of the time-space systematics. The Mekong delta (southern Cambodia and southern Vietnam) is an ideal setting for studying Southeast Asian's early brick technological tradition. Not only was the delta a crucible for social and political complexity during the early to midfirst millennium AD (Hall 1982, 1992; Stark 1998, 2003; Stark and Bong 2001): the level of archaeological activity on this period has accelerated in the last three decades.

Until recently, scholars dated brick monuments throughout the lower Mekong basin through comparison of their art and architectural styles with those found in South Asia (e.g., Parmentier 1927, 1932), or through dating inscriptions on stelae that were incorporated into the structures. Each of these approaches has generated a coarse-grained chronology that requires refinement. More recent efforts to use chronometric dating (e.g., Dao 1993) still concentrate on either associated statues of construction fill, rather than on the monument itself. Obtaining direct dates for a Southeast Asian brick technological tradition sheds lights on regional developments, on processes of technology transfer, and on historical trajectories in Southeast Asian and South Asian brick technological traditions.

We concentrate first on the earliest appearance of brick as a construction medium in South and Southeast Asia, whose use in secular construction dates to the late first millennium BC in South Asia. We then turn to evidence for the earliest use of brick in religious structures across the region, and discuss data from research through the Lower Mekong Archaeological Project. The current evidence suggests that secular brick construction preceded religious brick construction, and that this former technological development parallels, rather than lags behind, patterns described for South Asia.

\section{PATTERNS AND POSSIBLE ORIGIN AREAS}

\section{Empirical Patterns across the Region}

Residents in each of mainland Southeast Asia's first millennium states used brick to construct both secular and ritual structures. Chinese accounts of "Linyi," for example, describe the introduction of Chinese technological traditions like defensive settlement walls and ditches by the Chinese merchant adventurer Fan Wen in the AD 320s (Southworth 2004:220). The earliest ritual brick 
traditions in the region date between the 5th and 8th centuries $\mathrm{AD}$, from the Cham of central Vietnam to the Pyu in Burma's Dry Zone. In central Vietnam, the earliest preserved Cham brick and stone plinths (bases and platforms) at Tra Kieu and Po Nagar probably date from the 4th-5th centuries AD (W. Southworth, pers. comm., 2005).

Brick construction techniques appear later in the archaeological record of central and Northeast Thailand. Some scholars argue for the existence of Buddhist monuments as early as the third or fourth centuries $\mathrm{AD}$ in the Dvaravati region (e.g., Indrawooth 2004:138). Convincing evidence for the use of brick and laterite in stupa and caitya structures in central and Northeast Thailand, however, is dated to the 7th century AD, based on art styles and paleographic analysis (Higham 2002:256-257, 264265). These multiple lines of evidence support a 7th-8th century starting date for brick construction techniques in central and Northeast Thailand.

Brick architectural construction is also associated with the Pyu of Myanmar's Dry Zone, and also in southern Myanmar in the early centuries AD (Moore 2004:3). The conventional Pyu date range runs from the 1st - 9th centuries $\mathrm{AD}$, and scholars now agree that settlement occupation began before the construction of the encircling 2-5 meter thick brick walls that are a Pyu hallmark. Fingermarked bricks are ubiquitous on Pyu sites, and were used to construct settlement walls, in monastic buildings, and public buildings. Pyu bricks have never been dated directly, but radiocarbon dates associated with architectural beams from a brick-walled public hall at Beikthano range from the 1st -4 th centuries AD (Aung Thaw 1968:20, 23, 62). At the Pyu site of Halin, radiocarbon dates from structural timber and from two gateways range from the 1st - 8th centuries AD (Myint Aung 1970:57).

Most Cambodia scholars agree that brick monuments appeared by the beginning of the pre-Angkorian period (c. AD 500-802), and functioned primarily as repositories for Indic deities (Parmentier 1932:187). Funanese religious architecture may have consisted of brick foundations with wooden superstructures (Parmentier 1931:143), and their construction likely began after the mid-sixth century AD based on their absence from Chinese dynastic annals (Malleret 1962:349). Brick remained the primary construction medium until the late 9th century AD when both sandstone and laterite were added to the construction material repertoire. The use of brick continued throughout the Angkorian period and did not disappear completely until the end of the 11th century, and re-emerged as a building medium in the late 13th and early 14th centuries (Boisselier 1966:45-46). The highest density of preAngkorian inscriptions derives from Southern Cambodia's Mekong delta, and the delta's early brick tradition has received the most archaeological research attention in mainland Southeast Asia. French scholars like Jean Boisselier (1966) assigned this architecture to the end of the 7th century AD, based on related epigraphic and statuary evidence.
In the Mekong delta, civil war led to a three-decade research hiatus after Louis Malleret's $(1959,1960,1962)$ pioneering work at the Vietnamese site of Oc Eo. Vietnamese archaeologists resumed work on "Oc Eo Culture" sites in 1979 (Vo 2003). The Lower Mekong Archaeological Project (LOMAP) has worked in southern Cambodia since 1996 (Stark et al. 1999). A FrenchVietnamese cooperation program (involving the Institute of Social Sciences in Hô Chi Minh City and the École Française d'Extrême-Orient) worked intensively at the Oc Eo sites in southern Vietnam between 1997 and 2002. Their work concentrated on five areas in the vicinity of the modern pagoda of Linh Son (lower eastern slopes of $\mathrm{Ba}$ The), including brick architectural features (Manguin and Vo 2000).

Architectural and statuary evidence suggest that Vaishnavite and Buddhist cults became prominent in Mekong Delta sites during the 5th century. Often built upon foundations of large river boulders, few of the area's earliest brick structures remain in even fragmentary form. Three excavated architectural sites have been dated from southern Vietnam, and Luong describes them as "urban agglomerations" (Luong 2000:63). They are Ba The/Oc Eo (c. 5th - 6th centuries AD), Nen Chua (3rd - 6th centuries AD), and Go Thap (4th -5 th centuries AD). Almost two-thirds of the more than 50 stone, wood, and bronze statues that have been recovered from Vietnam's Mekong delta represent Buddha (Luong 2000:66). A total of four wooden Buddha statues have also been radiocarbon-dated (dates range from c.AD $300-600$ [Dao 1993:116]). Numerous dates have been obtained from fill associated with tombs, brick monuments, and "Oc Eo Culture" sites (Dao 1993). In sum, research in southern Vietnam emphasizes a 5th -7 th century AD florescence in brick architectural construction (Manguin and Vo 2000; Vo 1998, 2003).

\section{Possible Origin Areas}

Identifying potential geographic source areas for the Southeast Asian brick tradition would greatly enhance our ability to evaluate competing interpretations of the timing and relative influence of various South Asian regions on what is now mainland Southeast Asia. Early to mid-first millennium AD sites in most of Southeast Asia's early "core areas," however, lack sufficiently intact brick architecture to warrant systematic comparison with specific South Asian culture areas. This is especially true in the Mekong delta, most of whose brick monumental localities were reduced to surface or subterranean foundations by the time that Lunet de la Jonquiere published the results of his architectural survey (1901, 1902-1911). Today, partially intact buildings are exceedingly rare in either Vietnam or Cambodia (also see Trinh 1996: 122).

Given the paucity of architectural remains, most scholars have relied instead on comparisons of art traditions associated with temple lintels, or with statuary that the structures were built to house. Chinese accounts, as well as art historical evidence, suggests the co-existence of Hinduism and Buddhism across early Southeast Asia 
(e.g., Bhattacharya 1997:36). While Buddhism seemed to dominate the Pyu (Myanmar) and the Dvaravati (central Thailand) cultures, the Hindu religion generated a deeper material imprint in southern Cambodia and Vietnam than did Buddhism.

Elizabeth Moore notes that brick finger-marking, a Pyu hallmark, has parallels in Bihar, Uttar Pradesh and Kapilavastu, and was associated with the adoption of Theravada Buddhist practice in Myanmar and Thailand (Moore 2004:3). To the east into the Dvaravati homeland (and slightly later in time), Indrawooth (2004:139) argues that Dvaravati art bears affinities with (1) Nagarjunakonda in the Krishna-Godavari region of (Andhra Pradesh) when it was under Ikshvaku rule between AD 200-350 (p. 138) and (2) Mahayana Buddhism in Deccan India, and particularly by the Gupta and Vakataka rulers (c.AD 300-600).

In what is now Cambodia, pre-Angkorian art styles bear an even more mixed South Asian/Sri Lankan imprint. The Phnom Da art style reflects Mathura and Gupta artistic traditions (Boisselier 1989:31; Dalsheimer 2001:44), and shares similarities with statuary found throughout Peninsular Thailand and Malaysia. Numerous wooden, stone and bronze Buddha statues recovered from the Mekong delta resemble 6th century Amaravati traditions from Tamil Nadu (Boisselier 1966:266-267; Luong 1995). Boisselier (1966:60) concluded that the substantial diversity documented in pre-Angkorian architectural traditions reflected diverse sources of inspiration.

The unresolved debate over notions of "Indianization" (see Mabbett 1997 and Bellina and Glover 2004 for recent discussions) often obscures the importance of examining extant archaeological information on early brick technological traditions from both South and Southeast Asia. Comparing the earliest appearance of post-Harappan brick settlement boundary walls and brick religious architecture in these two regions provides one empirical tool for evaluating the relative timing of such processes and the historical implications of this information. The earliest stratigraphically dated brick temple in an archaeological context dates to the first century AD (Haertel 1993:86; Ray 2004a:348-349), although earlier temples with brick plinths and foundations may have been constructed a few centuries earlier. The earliest surviving brick temples date from the 4th - 6th centuries AD during the Gupta period (Kramrisch 1976:101-102; Ray 2004b: 351), while stone architectural traditions began to flourish after the 4th century AD (Michell 1988:18; Ray 2004b:350). These early temples shared sacred space with a variety of domestic, local and regional cults, and coincide with the earliest well-dated Hindu images and iconography (e.g., Michell 2000:42-43). The manufacture and usage of brick for Hindu temples required particular protocol and bore specific religious connotations: bricks form the "body of the sacrifice (yajñatanu)" (Kramrisch 1976:102).

Areas of southern India that flank coastal Bengal like Tamil Nadu and Andhra Pradesh were particularly important source regions for the spread of Buddhism through the Bay of Bengal and into mainland Southeast Asia (Bel- lina and Glover 2004; Ray 2005). Secular brick coastal structures have been reported from the 3rd century BC, based on brick dimensions (Gaur et al. 2005). Brick Brahmanical shrines appeared as early as the first century AD across much of southern India (e.g., Sarma 1983; Krishna Murthy 1983: 65). In this region, Brahmanical temples did not appear before the 4th - 5th centuries AD and the earliest well-dated religious structures date to the 7th century AD (Ray 1997:45-46).

These comparative data form an essential foundation for studying the timing of the earliest secular and ritual brick construction in the Mekong delta. Comparative art styles suggest a 3rd - 7th century AD date range for temple construction, while South Asian evidence for brick religious structures begins in earnest by the 2 nd century AD. However, the lack of directly-dated brick from any site across mainland Southeast Asia is a major impediment to understanding this process. Chronometric research on brick construction features in and around Angkor Borei (southern Cambodia) provides some of the earliest secure dates for brick architecture in the region. This paper presents preliminary results of the dating program at Angkor Borei and its surrounding monuments, and also examines the utility of luminescence techniques for dating historic period monuments across mainland Southeast Asia.

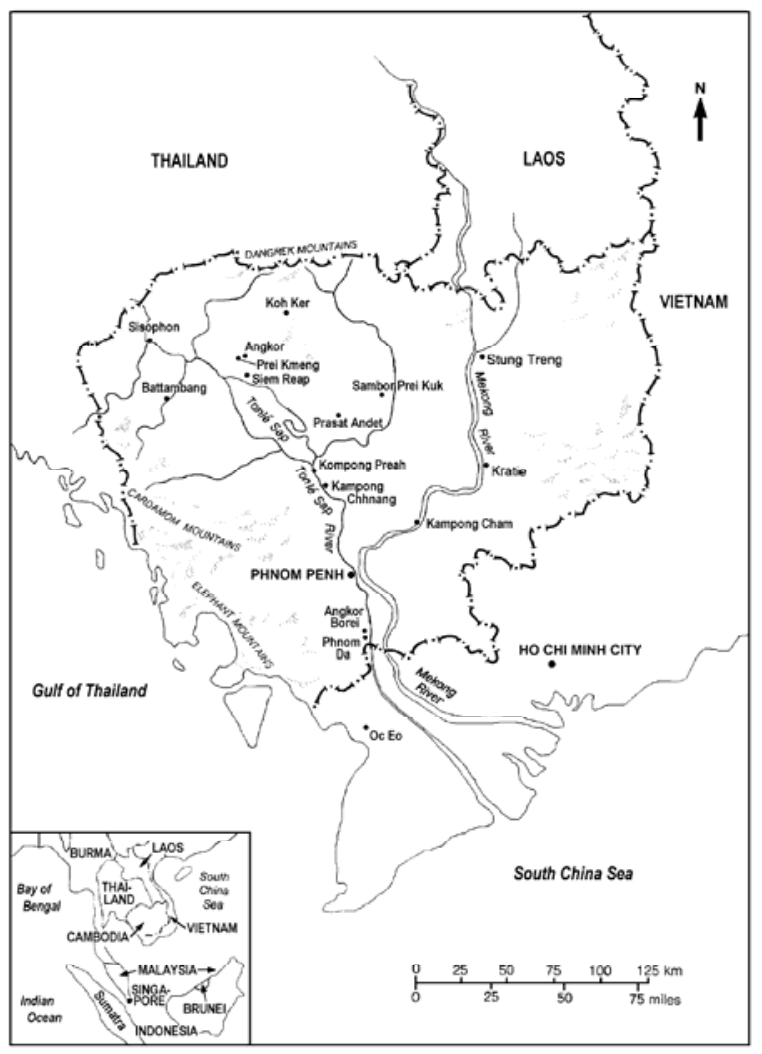

Figure 1. Locational Map of Angkor Borei in southern Cambodia. Reprinted with permission from the University of Hawaii Press from Figure 1, p. 52 in "A New Date for the Phnom Da Images and Its Implications for Early Cambodia." by N.H. Dowling, Asian Perspectives 38(1):51-61. 


\section{RESEARCH AT ANGKOR BOREI}

Work by LOMAP, in collaboration with Cambodia's Ministry of Culture and Fine Arts, concentrates in and around the southern Cambodian site of Angkor Borei, in Takeo Province (Figure 1). The archaeological site of Angkor Borei has been the focus of art historical and historical interest since the late 19th century (Aymonier 1901), because of its monumental wall, its collapsed brick structures, its artifacts, and its associated Phnom Da art style, the latter of which represents the earliest Khmer art tradition. Many historians, following Chinese accounts (Pelliot 1903), believe that Angkor Borei was an inland capital of Cambodia's earliest civilization, which Chinese visitors from the 3rd - 6th centuries AD called Funan (Coedès 1968; Wheatley 1983).

Previous publications have reported on LOMAP research findings at the site of Angkor Borei; these focus on the site's size, configuration, and occupational history (Stark et al. 1999; Stark 1998, 2003). Also notable are the existence of brick monumental features (both structures and a surrounding wall), and a range of satellite settlements that were linked to Angkor Borei by artificial and natural waterways.

Dating brick monument samples from Angkor Borei is important for understanding the settlement's developmental history, its relative influence at different points in time, and the origins and age of stone sculptures that were placed within these monuments and have thus far been the exclusive purview of art historians.

\section{LOMAP LUMINESCENCE DATING PROGRAM AT ANGKOR BOREI}

Twelve brick samples from six localities within the Angkor Borei site have been sampled as part of the LOMAP luminescence dating program thus far. Brick samples from two types of primary contexts were sampled (i.e., secular [perimeter wall] and sacred [shrines and temples]), and three phases of the brick luminescence program have thus been completed: (1) a 1997 pilot luminescence study of two bricks from collapsed monuments at Angkor Borei, including one that LOMAP members investigated in 1996; (2) the 1999-2003 focus on the perimeter wall surrounding Angkor Borei; and (3) the 2004 work on collapsed brick monuments within Angkor Borei and its general catchment area (Sanderson and Bingham 2004a, 2004b). Analytical work has involved both optically stimulated luminescence and thermoluminescence. These samples were analyzed using a Single Aliquot Regenerative (SAR) Optically-Stimulated Luminescence (OSL) procedure on extracted quartz grains. In-depth contextual, methodological, and analytical descriptions have been presented in previous reports (Feathers 1997; Sanderson and Bingham 2004a, 2004b), and are not discussed in this article.

We begin with the Angkor Borei perimeter wall, which Groslier (1935:491) first described, and which has been the focus of continuing LOMAP field investigation since 1996. Previous trenching activities indicate that at least some sections of the wall were 2.4 meters wide and 4.5 meters tall, that the wall's dimensions may have varied from one point to another, and that the wall was constructed using core-veneer methods (Stark et al. 1999:2223). Angkor Borei wall bricks conform closely to the preAngkorian brick technology described by Jean Boisselier (1966): they incorporate rice chaff rather than mineral temper, and were made in relatively standardized sizes (c. $10 \times 20 \times 40 \mathrm{~cm}$ ) that parallel the pre-Angkorian bricks that Boisselier (1966:46) recorded (i.e., from $25 \times 14 \mathrm{x}$ $5.7 \mathrm{~cm}$ to $31 \times 16 \times 8.5 \mathrm{~cm})$. Inclusion of organic, rather than mineral, temper may be indicative of local manufacture, while the standardized dimensions could indicate the use of mold construction techniques.

Table 1 presents findings of LOMAP brick luminescence dating thus far, and we concentrate first on Angkor Borei's perimeter wall. In sum, we sampled four bricks collected from each of the two wall sections and found that individual OSL ages from the bricks ranged from $170 \pm 150 \mathrm{BC}$ to $\mathrm{AD} 420 \pm 120$, with individual errors of the order of $5-10 \%$ of age. Results from $\mathrm{AB} 8$, an artificial wall cut made by a farmer to drain his fields, provided a mean age of AD $65 \pm 90$. Samples recovered from AB9, the southeastern most wall remnant (but not the wall's original southeastern corner), provided a mean age of $\mathrm{AD}$ $270 \pm 90$. Subsequent radiocarbon dating of a carbonized rice grain from this latter location yielded a calibrated date of AD 240 - 420, which closely parallels dates produced from the seven luminescence samples.

These conflicting results suggest either that we are underestimating luminescence errors for some reason, or that the brick ages are not synchronous. The local averages of $\mathrm{AB} 8$ and $\mathrm{AB} 9$ sections are themselves internally consistent, however, and the AB9 radiocarbon date accords well with the luminescence dates. Interestingly, the mean age of $\mathrm{AB} 8$ and $\mathrm{AB} 9$ are more probably different than the same; we interpret these results as indicating that the Angkor Borei wall contains bricks of more than one age.

Although LOMAP crew members have documented no fewer than 15 collapsed brick monuments within the walled site of Angkor Borei, few are sufficiently intact to merit documentation and sampling for dating. One of these, called “AB-5" (Stark et al. 1999:22-25) was sampled in 1996 and luminescence dates proved problematic (Table 1). Feathers (1997) suggested that brick samples from this temple may not have been fired, and recommended reliance on optically-stimulated luminescence techniques. Although bricks sampled from multiple locations in 2001 and 2004 by the Scottish Universities Environmental Research Centre (SUERC) laboratory suggest some firing activity, Feathers' recommendation of optical techniques proved useful.

A second brick building from Angkor Borei, now dubbed Ba Srê (previously "Vishnu temple" [Stark et al. 1999:26-27]), was also sampled in 1996, and has produced more reliable dates than "AB-5" (Table 1). Local authorities sanctioned the dismantling of this feature (which reportedly included some bulldozing) following 
Table 1. Sampling details for all bricks collected during LOMAP 1997-2004.

\begin{tabular}{|c|c|c|c|c|c|}
\hline Locality & $\begin{array}{l}\text { Context description } \\
\text { (\& site) }\end{array}$ & $\begin{array}{l}\text { Brick } \\
\text { label }\end{array}$ & Lab no. & Sample description & Luminescence Lab \\
\hline \multirow{3}{*}{$\begin{array}{l}\text { Phnom } \\
\text { Toch }\end{array}$} & \multirow{3}{*}{$\begin{array}{l}\text { Very disturbed struc- } \\
\text { ture in eastern sector } \\
\text { (Angkor Borei). }\end{array}$} & $\mathrm{A}$ & SUTL1560 & Central brick sample. & SUERC (Sanderson and Bingham) \\
\hline & & $\mathrm{B}$ & SUTL1561 & Brick sample adjacent to A. & SUERC (Sanderson and Bingham) \\
\hline & & $\mathrm{C}$ & SUTL1563 & $\begin{array}{l}\text { Brick sample from one course } \\
\text { below samples A and B. }\end{array}$ & SUERC (Sanderson and Bingham) \\
\hline \multirow[t]{3}{*}{ Ta Tos } & \multirow{3}{*}{$\begin{array}{l}\text { Moated mound in } \\
\text { southern sector (Ang- } \\
\text { kor Borei) }\end{array}$} & $\mathrm{A}$ & SUTL1565 & $\begin{array}{l}\text { Central brick sample and associ- } \\
\text { ated soil. }\end{array}$ & SUERC (Sanderson and Bingham) \\
\hline & & $\mathrm{B}$ & SUTL1566 & Central brick sample. & SUERC (Sanderson and Bingham) \\
\hline & & $\mathrm{C}$ & SUTL1567 & $\begin{array}{l}\text { Peripheral brick sample and } \\
\text { associated soil. }\end{array}$ & SUERC (Sanderson and Bingham) \\
\hline $\begin{array}{l}\text { "Vishnu" } \\
\text { or Ba Srê } \\
\text { temple }\end{array}$ & $\begin{array}{l}\text { Temple immed. South } \\
\text { of east-west river divid- } \\
\text { ing site (Angkor Borei) }\end{array}$ & $\mathrm{n} / \mathrm{a}$ & UWTL258 & $\begin{array}{l}\text { Central brick sample (from } \\
\text { disturbed temple core) and asso- } \\
\text { ciated soil along eastern edge of } \\
\text { monument }\end{array}$ & UWashington TL Lab (Feathers) \\
\hline $\begin{array}{l}\text { AB-5 } \\
\text { temple }\end{array}$ & $\begin{array}{l}\text { Temple in east-central } \\
\text { area (Angkor Borei) }\end{array}$ & $\mathrm{n} / \mathrm{a}$ & UWTL257 & $\begin{array}{l}\text { ? temple platform? from center } \\
\text { of structure }\end{array}$ & UWashington TL Lab (Feathers) \\
\hline AB-8 & $\begin{array}{l}\text { Eastern cut in wall } \\
\text { (Angkor Borei) }\end{array}$ & & SUTL1510 & $\begin{array}{l}\text { From arbitrary cut in eastern } \\
\text { wall, c. } 20 \text { meters north of } \\
\text { southeasternmost extant exten- } \\
\text { sion of wall }\end{array}$ & SUERC (Sanderson and Bingham) \\
\hline AB-8 & $\begin{array}{l}\text { Eastern cut in wall } \\
\text { (Angkor Borei) }\end{array}$ & & SUTL1511 & $\begin{array}{l}\text { From arbitrary cut in eastern } \\
\text { wall, c. } 20 \text { meters north of } \\
\text { southeasternmost extant exten- } \\
\text { sion of wall (but not real corner) }\end{array}$ & SUERC (Sanderson and Bingham) \\
\hline AB-8 & $\begin{array}{l}\text { Eastern cut in wall } \\
\text { (Angkor Borei) }\end{array}$ & & SUTL1512 & $\begin{array}{l}\text { From arbitrary cut in eastern } \\
\text { wall, c. } 20 \text { meters north of } \\
\text { southeasternmost extant exten- } \\
\text { sion of wall (but not real corner) }\end{array}$ & SUERC (Sanderson and Bingham) \\
\hline AB-8 & $\begin{array}{l}\text { Eastern cut in wall } \\
\text { (Angkor Borei) }\end{array}$ & & SUTL1513 & $\begin{array}{l}\text { From arbitrary cut in eastern } \\
\text { wall, c. } 20 \text { meters north of } \\
\text { southeasternmost extant exten- } \\
\text { sion of wall (but not real corner) }\end{array}$ & SUERC (Sanderson and Bingham) \\
\hline AB-9 & $\begin{array}{l}\text { Extant "corner" of wall } \\
\text { (Angkor Borei) }\end{array}$ & & SUTL1514 & $\begin{array}{l}\text { Southeasternmost extant exten- } \\
\text { sion of wall (but not real corner) }\end{array}$ & SUERC (Sanderson and Bingham) \\
\hline AB-9 & $\begin{array}{l}\text { Extant "corner" of wall } \\
\text { (Angkor Borei) }\end{array}$ & & SUTL1515 & $\begin{array}{l}\text { Southeasternmost extant exten- } \\
\text { sion of wall (but not real corner) }\end{array}$ & SUERC (Sanderson and Bingham) \\
\hline AB-9 & $\begin{array}{l}\text { Extant "corner" of wall } \\
\text { (Angkor Borei) }\end{array}$ & & SUTL1516 & $\begin{array}{l}\text { Southeasternmost extant exten- } \\
\text { sion of wall (but not real corner) }\end{array}$ & SUERC (Sanderson and Bingham) \\
\hline AB-9 & $\begin{array}{l}\text { Extant "corner" of wall } \\
\text { (Angkor Borei) }\end{array}$ & & SUTL1517 & $\begin{array}{l}\text { Southeasternmost extant exten- } \\
\text { sion of wall (but not real corner) }\end{array}$ & SUERC (Sanderson and Bingham) \\
\hline $\begin{array}{l}\text { Ang Yay } \\
\text { Noun }\end{array}$ & $\begin{array}{l}\text { Moated mound of 50- } \\
100 \mathrm{~m} \text { dimensions }\end{array}$ & $\mathrm{n} / \mathrm{a}$ & SUTL1568 & $\begin{array}{l}\text { Exposed brick } 5-10 \mathrm{~m} \text { from } \\
\text { centre of mound and associated } \\
\text { soil. }\end{array}$ & SUERC (Sanderson and Bingham) \\
\hline \multirow{4}{*}{$\begin{array}{l}\text { Ang Dom- } \\
\text { bouk Neak } \\
\text { Ta }\end{array}$} & \multirow{4}{*}{$\begin{array}{l}\text { Brick structure with } \\
\text { stone foundations } \\
\text { emerging from earth } \\
\text { mound near Phnom } \\
\text { Thun Mun. }\end{array}$} & A1 & SUTL1573 & $\begin{array}{l}\text { Brick from inner face of ante- } \\
\text { chamber wall. }\end{array}$ & SUERC(Sanderson and Bingham) \\
\hline & & $\mathrm{A} 2$ & SUTL1574 & $\begin{array}{l}\text { Brick from inner face of ante- } \\
\text { chamber wall. }\end{array}$ & SUERC(Sanderson and Bingham) \\
\hline & & $\mathrm{B} 1$ & SUTL1575 & $\begin{array}{l}\text { Brick from third course above } \\
\text { stone foundation. }\end{array}$ & SUERC (Sanderson and Bingham) \\
\hline & & B2 & SUTL1576 & $\begin{array}{l}\text { Brick from third course above } \\
\text { stone foundation. }\end{array}$ & SUERC (Sanderson and Bingham) \\
\hline \multirow{2}{*}{$\begin{array}{l}\text { Neak Ta } \\
\text { Chvia }\end{array}$} & \multirow{2}{*}{$\begin{array}{l}\text { Rural mound close to } \\
\text { Phnom Thun Mun. }\end{array}$} & Upper & SUTL1557 & Central brick fragment. & SUERC (Sanderson and Bingham) \\
\hline & & Lower & SUTL1558 & $\begin{array}{l}\text { Brick fragment from near base } \\
\text { and associated soil. }\end{array}$ & SUERC (Sanderson and Bingham) \\
\hline \multirow{4}{*}{$\begin{array}{l}\text { Tuol Kam } \\
\text { Nap }\end{array}$} & \multirow{4}{*}{$\begin{array}{l}\text { Moated mound east of } \\
\text { Prey Phkoam }\end{array}$} & $\mathrm{A}$ & SUTL1569 & Central brick fragment. & SUERC (Sanderson and Bingham) \\
\hline & & $\mathrm{B}$ & SUTL1570 & $\begin{array}{l}\text { Brick fragment } 5 \text { courses below } \\
\mathrm{A} \text { and at current soil surface. }\end{array}$ & SUERC (Sanderson and Bingham) \\
\hline & & $\mathrm{C}$ & SUTL1571 & Central brick fragment. & SUERC (Sanderson and Bingham) \\
\hline & & $\mathrm{D}$ & SUTL1572 & $\begin{array}{l}\text { Brick fragment } 3 \text { courses below } \\
\text { C. }\end{array}$ & SUERC (Sanderson and Bingham) \\
\hline Paris 4 & $\begin{array}{l}\text { Canal section south of } \\
\text { Phnom Borei. }\end{array}$ & $\mathrm{n} / \mathrm{a}$ & SUTL1564 & $\begin{array}{l}\text { Submerged brick recovered } \\
\text { from Paris } 4 \text { canal trench. }\end{array}$ & SUERC(Sanderson and Bingham) \\
\hline
\end{tabular}


Table 2. Luminescence dates for all bricks analyzed from LOMAP 1997-2004 field seasons. Calibrated using Stuiver et al. 1998.

\begin{tabular}{|c|c|c|c|c|c|}
\hline Locality & $\begin{array}{l}\text { Brick } \\
\text { label }\end{array}$ & Lab no. & OSL date & $\begin{array}{l}\text { Radiocarbon date ( } 2 \\
\delta \text { cal) }\end{array}$ & Weighted average \\
\hline \multirow[t]{3}{*}{ Phnom Toch } & $\mathrm{A}$ & SUTL1560 & $\mathrm{AD} 700 \pm 60$ & $\begin{array}{ll}--- \\
\end{array}$ & $\mathrm{n} / \mathrm{a}$ \\
\hline & $\mathrm{B}$ & SUTL1561 & AD $930 \pm 20$ & ---- & $\mathrm{n} / \mathrm{a}$ \\
\hline & $\mathrm{C}$ & SUTL1563 & $\mathrm{AD} 720 \pm 30$ & $\begin{array}{ll}--- \\
--1\end{array}$ & $\mathrm{n} / \mathrm{a}$ \\
\hline \multirow[t]{3}{*}{ Ta Tos } & $\mathrm{A}$ & SUTL1565 & $\mathrm{AD} 320 \pm 30$ & $\begin{array}{ll}--- \\
\end{array}$ & $\mathrm{n} / \mathrm{a}$ \\
\hline & $\mathrm{B}$ & SUTL1566 & $\mathrm{AD} 95 \pm 30$ & ---- & $\mathrm{n} / \mathrm{a}$ \\
\hline & $\mathrm{C}$ & SUTL1567 & AD 570 430 & ---- & $\mathrm{n} / \mathrm{a}$ \\
\hline Vishnu & $\mathrm{n} / \mathrm{a}$ & UWTL258 & AD $928 \pm 132$ & --- & AD $965 \pm 116$ \\
\hline AB-5 temple & $\mathrm{n} / \mathrm{a}$ & UWTL257 & $\mathrm{AD} 1272 \pm 295$ & --- & $\mathrm{n} / \mathrm{a}$ \\
\hline AB-8 & & SUTL1510 & $\mathrm{AD} 240 \pm 130$ & --- & $\mathrm{n} / \mathrm{a}$ \\
\hline AB-8 & & SUTL1511 & AD $180 \pm 170$ & --- & $\mathrm{n} / \mathrm{a}$ \\
\hline AB-8 & & SUTL1512 & $25 \pm 150 \mathrm{BC}$ & --- & $\mathrm{n} / \mathrm{a}$ \\
\hline AB-8 & & SUTL1513 & $170 \pm 150 \mathrm{BC}$ & --- & \\
\hline AB-9 & & SUTL1514 & $\mathrm{AD} 120 \pm 150$ & --- & $\mathrm{n} / \mathrm{a}$ \\
\hline AB-9 & & SUTL1515 & $\mathrm{AD} 420 \pm 120$ & --- & $\mathrm{n} / \mathrm{a}$ \\
\hline AB-9 & & SUTL1516 & --- & Cal AD $240-420^{1}$ & $\mathrm{n} / \mathrm{a}$ \\
\hline AB-9 & & SUTL1517 & $\mathrm{AD} 170 \pm 180$ & -- & $\mathrm{n} / \mathrm{a}$ \\
\hline Ang Yay Noun & $\mathrm{n} / \mathrm{a}$ & SUTL1568 & $\mathrm{AD} 650 \pm 50 \mathrm{AD}$ & --- & $\mathrm{n} / \mathrm{a}$ \\
\hline \multirow{4}{*}{$\begin{array}{l}\text { Ang Dombouk Neak } \\
\text { Ta }\end{array}$} & A1 & SUTL1573 & $\mathrm{AD} 600 \pm 20$ & $\begin{array}{ll}-- \\
\end{array}$ & $\mathrm{n} / \mathrm{a}$ \\
\hline & $\mathrm{A} 2$ & SUTL1574 & AD 560土30 & --- & $\mathrm{n} / \mathrm{a}$ \\
\hline & $\mathrm{B} 1$ & SUTL1575 & $\mathrm{AD} 860 \pm 20$ & --- & $\mathrm{n} / \mathrm{a}$ \\
\hline & B2 & SUTL1576 & AD $840 \pm 20$ & --- & $\mathrm{n} / \mathrm{a}$ \\
\hline \multirow[t]{2}{*}{ Neak Ta Chvia } & Upper & SUTL1557 & $\mathrm{AD} 470 \pm 40$ & --- & $\mathrm{n} / \mathrm{a}$ \\
\hline & Lower & SUTL1558 & $\mathrm{AD} 630 \pm 30$ & --- & $\mathrm{n} / \mathrm{a}$ \\
\hline \multirow[t]{4}{*}{ Tuol Kam Nap } & A & SUTL1569 & $\mathrm{AD} 940 \pm 40$ & --- & $\mathrm{n} / \mathrm{a}$ \\
\hline & $\mathrm{B}$ & SUTL1570 & $\mathrm{AD} 800 \pm 50$ & --- & $\mathrm{n} / \mathrm{a}$ \\
\hline & $\mathrm{C}$ & SUTL1571 & AD $1040 \pm 20$ & --- & $\mathrm{n} / \mathrm{a}$ \\
\hline & $\mathrm{D}$ & SUTL1572 & AD $1120 \pm 20$ & --- & $\mathrm{n} / \mathrm{a}$ \\
\hline Paris 4 & $\mathrm{n} / \mathrm{a}$ & SUTL1564 & AD $180 \pm 20$ & --- & $\mathrm{n} / \mathrm{a}$ \\
\hline
\end{tabular}

the 1995 rainy season, and at least two fragmentary sandstone statues were uncovered during the process. One of these, a mitred Vishnu, was given to Cambodia's National Museum of Phnom Penh by Prime Minister Hun Sen and dates to the late 7th/early 8 th centuries AD (Dalsheimer 2001:58).

We offer the following conclusions regarding our dating program at the Angkor Borei perimeter wall. First, all results are predate $\mathrm{AD} 600$ and thus fall within the "Funan" period. Our radiocarbon date from AB9 provides independent support for the OSL chronology. Second, we find the null hypothesis (i.e., that all bricks are of same

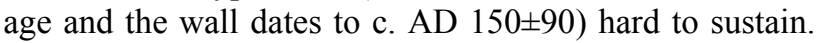
Either the wall was a mid-1st millennium structure that incorporated older bricks, the wall was repaired through time (and thus incorporated older bricks), or the wall was constructed in episodic activities over several centuries. Additional excavations and sampling is necessary to resolve these issues.

\section{LUMINESCENCE DATING PROGRAM DURING THE LOMAP 2003-2005 SURVEY}

Luminescence dating was also undertaken on four fragmentary brick monuments that were documented in the LOMAP 2003-2005 archaeological survey, which focuses on the catchment system surrounding the Takeo River (including the Plain of Reeds, Bassac and Mekong Rivers that are located east of Angkor Borei, Figure 2). For topographic reasons the survey region fans westward and southward from Angkor Borei. LOMAP field survey involved surface mapping and collections of approximately 280 mound or moat-mound features. This work recovered a range of materials that may date as far back as the Bronze Age (and as late as the Angkorian period); most ceramic collections dated to the first half of the first millennium $\mathrm{AD}$.

Three primary site types were identified (i.e., moatmounds, artifact concentrations, and water control features) and in some cases, site clusters contained all three types. The vast majority of sites we documented had one or more moated mounds, and these were commonly located away from contemporary Khmer villages in prime agricultural areas. One of the greatest challenges lies in dating these sites, only some of which have surface materials. We acknowledge that our reliance on remote sensing and informant interview methodologies to locate sites, as well as the alluviation processes endemic to the region, bias our results toward first millennium $\mathrm{AD}$ sites, and under-represents surface scatters and earlier (now covered) occupational periods.

A variety of collapsed brick monuments were recorded, but none consisted of intact standing structures. 


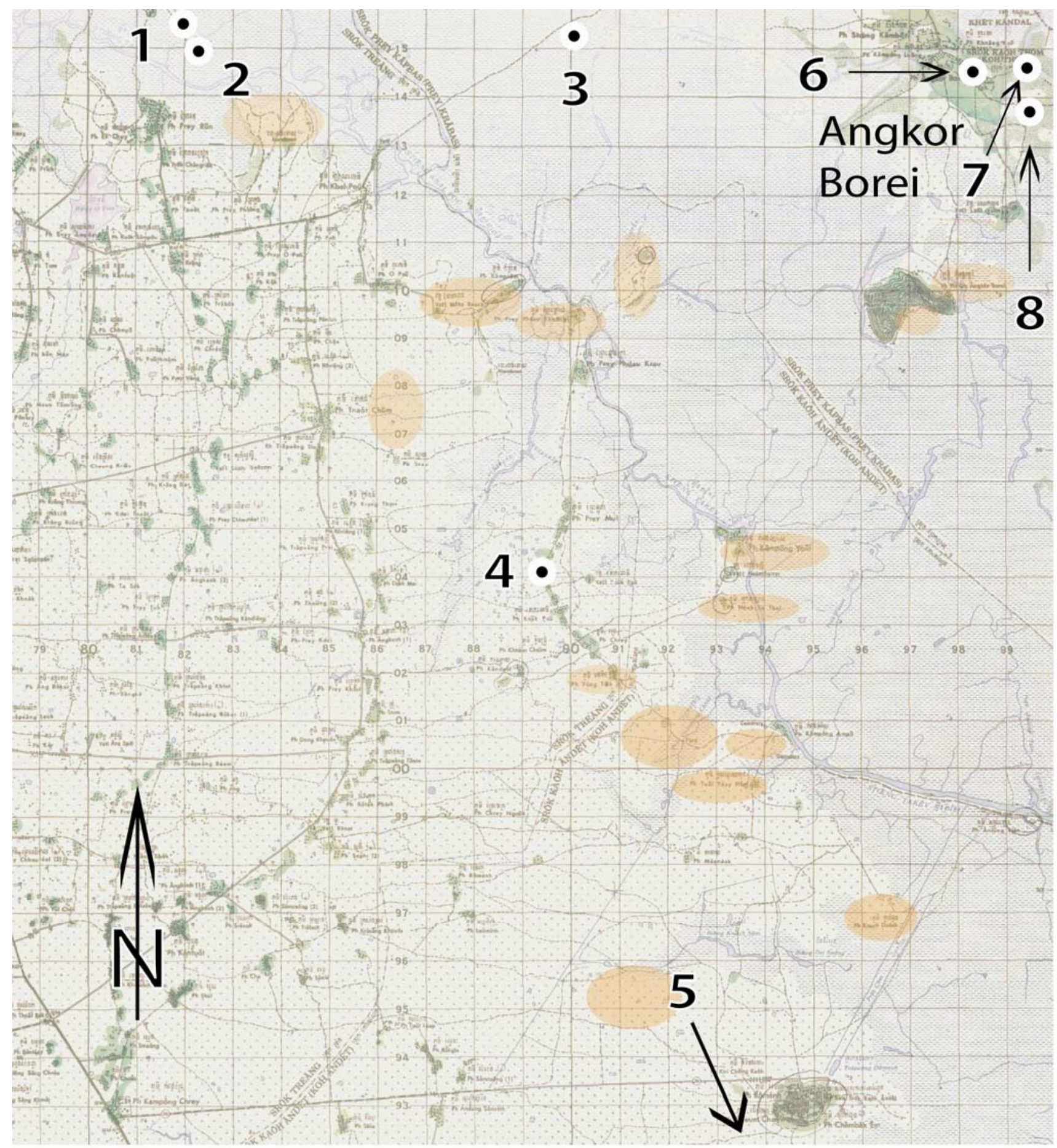

Figure 2. Locations of sampled brick monuments in LOMAP 2003-2005 survey region in Takeo Province. 1 . Thun Mun ( $6^{\text {th }}-9^{\text {th }}$ centuries $A D) ; 2$. Neak Ta Chvia $\left(6^{\text {th }}-7^{\text {th }}\right.$ centuries AD); 3. Tuol Kamnap $\left(9^{\text {th }}-12^{\text {th }}\right.$ centuries AD); 4. Any Yay Nuon $\left(7^{\text {th }}\right.$ century AD); 5. Paris Canal \#4 canal segment ( $2^{\text {nd }}$ century AD?); 6. Ba Srê/Vishnu Temple $\left(10^{\text {th }}\right.$ century AD); 7. Phnom Poch $\left(8^{\text {th }}-10^{\text {th }}\right.$ centuries AD); 8. Ta Tos $\left(1^{\text {st }}-6^{\text {th }}\right.$ centuries $\left.A D\right)$.

Most sites with brick remains were in such poor condition that it was impossible to decipher the original construction plan; in rare cases, intact masonry fragments remained. Results from the Angkor Borei wall luminescence-dating program offered the intriguing possibility that brick structures existed in the vicinity of Angkor Borei in the late 1st millennium BC and early 1st millen- nium AD. Accordingly, we obtained permission to sample four of these along the Takeo River, and two within the walled area of Angkor Borei. Field sampling methods followed protocols used by David Sanderson's SUERC luminescence laboratory, and were combined with standard archaeological recording procedures. 
Results from the 2004 small sites luminescence-dating program further complicate the chronology of this portion of southern Cambodia. Here we offer preliminary luminescence results, bearing in mind that final calibrations are necessary to take into account systematic errors (e.g., source calibration, uncertainties on dose rate conversion factors) and overall errors. Luminescence dates from these sites are consistently and substantially later in time than those produced for the Angkor Borei wall. In fact, samples from collapsed brick monuments along the Takeo River yielded post-Funan dates, as was the case with the site of Tuol Kamnap. Interestingly, so did some collapsed brick monuments within Angkor Borei, including the substantial mound of Phnom Toch, whose bricks and cobble foundations are currently being mined for construction materials.

Table 2 indicates that Angkor Borei monuments date to both the early and late 1 st millennium AD. Radiocarbon dates from previous LOMAP excavations (Stark and Bong 2001; Stark et al. 1999) offer an initial occupation date for the site in the 5 th or 4th century BC, which suggests that Angkor Borei experienced multiple occupation phases. Monuments along Takeo River which may have been satellite settlements to Angkor Borei date to the 7th 10th centuries AD. The temporal contrast between the Angkor Borei wall dates and the brick monument dates are particularly interesting, given that our 2004 trenching operations at the alleged Paris 4 canal (that linked Angkor Borei to Oc Eo) recovered a brick (SUTL1564) whose luminescence date is c. AD $180 \pm 20$.

The provisional results of our luminescence dating program confirm the presence of a 1 st - 6th century AD brick wall around Angkor Borei, which predates the fluorescence of Oc Eo by several centuries; the lone brick recovered from the Paris 4 canal that linked Angkor Borei to Oc Eo is suggestive of some early first millennium AD brick usage across the region. We also have significant evidence for mid-1st millennium brick construction in the form of brick monuments, away from (but probably related to) Angkor Borei in the northern Mekong delta that parallels the emergence of Oc Eo. Equally interesting is the fact that we have substantial evidence for brick monumental construction throughout some of the northern delta after the "collapse" of the polity associated with Funan. LOMAP survey crews in 2004 and 2005 also recorded significant numbers of Angkorian-period sites. So have Vietnamese archaeologists on their side of the delta (Vo 2003), although the majority of dated brick monuments in southern Vietnam predate AD 1000 (Vo 1998). Evidently, mid-first millennium AD monuments were renovated subsequent to their initial construction, and populations also continued to build brick monuments in the delta for many centuries after the 'collapse' of Funan in the 6th - 7th centuries AD.

\section{DISCUSSION AND IMPLICATIONS}

In this paper we have identified some broader issues on which our brick dating program inform, most notably the timing and directionality of South-Southeast Asia influ- ence in the development and implementation of a brick technological tradition. Given the corroboration of radiocarbon and luminescence dates for Angkor Borei's perimeter wall, we feel certain in assigning this wall's initial construction episode to an early 1 st millennium AD date, and believe that the wall experienced multiple subsequent building or remodelling events. Although later PreAngkorian brick constructions are directly associated with elite donations and tributary activities (e.g., Vickery 1998), the earliest public works in the region were secular and may have predated the widespread adoption of Indic ideas and their associated "merit" system of religious coercion.

We feel equally certain that the brick religious monuments we sampled postdate the Angkor Borei wall by several centuries. Comparison of LOMAP work in Cambodia with recent work by the French-Vietnamese team (1997-2002) is the first step toward building a regional Mekong delta perspective. The "Oc Eo culture" thus coincides satisfactorily with dates from the monuments our survey has recorded in the northern delta (around Angkor Borei), but not with the establishment of Angkor Borei, nor with the initiation of its wall construction. Both these events predate the "Oc Eo culture" brick monumental tradition by several centuries. Previous research suggests that the practice of moat and wall construction in mainland Southeast Asia extends back to at least to the first millennium BC (Higham 2002; Moore 1988, 1992:43). It is perhaps not surprising that the brick wall construction sequence is several centuries earlier than that of the brick buildings, and may fall into the period that Bellina and Glover (2004) describe as the most intensive period of South-Southeast Asian interaction.

Results from this luminescence program will help refine the regional chronology of the upper Mekong delta, perhaps even beyond Takeo Province. Use of brick luminescence dating techniques may also shed light on broader and related issues of architecture and art history. One of these concerns the origins and timing of South Asian versus Southeast Asian architectural traditions. Perhaps the Southeast Asian brick tradition did not lag as far behind South Asia as previously imagined, but instead took different forms.

The second broader issue involves controversies surrounding the ages of the region's earliest "pre-Angkorian" art, including (but not limited to) mitred Vishnu statuary (e.g., Dalsheimer and Manguin 1998; Lavy 2003). Many of these brick monuments were built explicitly to house the Indic statuary whose earliest construction date is variously placed in the 5 th, 6 th or 7 th centuries and the dating of this pre-Angkorian tradition remains a matter of some debate. Although our primary goal in directly dating the monuments that housed these sculptures is to establish a regional settlement sequence, our luminescence program may also help resolve some of these debates in art history that previously relied, in large part, on stylistic analyses.

Vietnamese and French research indicates that some Oc Eo region religious brick monuments date as early as the 5th century AD. Our ongoing dating program indi- 
cates that a similar pattern may be obtained in the northern delta around Angkor Borei. We await results of future work on Angkor-region brick monuments to ascertain whether this pattern has an even broader geographic distribution. That this monumental construction tradition developed simultaneously across much of the Mekong delta, and in concert with a relatively uniform statuary tradition, has both social and ideological implications regarding the region's relative integration. Additional dating in other areas of mainland Southeast Asia is necessary to explore the implications of these findings, which include the directionality of influence and the issue of emulation vs. convergence (see also Kulke 1990; Mabbett 1997; Smith 1999).

This paper has presented preliminary results of the luminescence-dating program through the Lower Mekong Archaeological Project. Our work thus far has contributed to the culture history of the northern Mekong delta, and to understanding the development of Angkor Borei and its surrounding area. We hope it has also demonstrated that the use of archaeometric analytical methods in conjunction with archaeological work is capable of revealing new facets of the social developments of these early complex systems. But such work cannot be undertaken in a vacuum, and we encourage our colleagues to consider the use of luminescence techniques for dating historic period brick monuments in other regions of mainland Southeast Asia.

\section{ACKNOWLEDGMENTS}

Field work was supported by grants from the National Geographic Society, the Foundation for Research and Exploration on Cultural Origins (FERCO), the National Endowment for the Humanities, and the National Science Foundation. Our special thanks go to Cambodian colleagues, including Minister of Culture Her Royal Highness Princess Norodom Bopha Devi, His Royal Highness Prince Sisowath Pannara, and His Excellency Chuch Phoeurn for permission to undertake research. We also thank colleagues at the Royal University of Fine Arts (Ministry of Culture and Fine Arts) for continued collaboration in our research in Angkor Borei. Thanks also go to LOMAP crew members from the 1996, 1999, 2001, and 2003-2005 field seasons, and especially to Phon Kaseka, Ya Da, and Heng Piphal. Comments from Himanshu Ray and Ben Marwick improved this paper's content, and Jo Lynn Gunness provided graphics assistance with Figure 1. We also thank the community of Angkor Borei and of Takeo Province for their kind assistance and cooperation throughout our fieldwork.

\section{REFERENCES}

Aung Thaw, U. 1968. Report on the Excavations at Beikthano. Rangoon.

Aymonier, E. 1900-1904. Le Cambodge. Paris: 3 vols. E. Leroux.

Bellina, B. and I. Glover. 2004 . The archaeology of early contact with India and the Mediterranean world, from the fourth century BC to the fourth century AD. In I. Glover and P. Bellwood (eds.), Southeast Asia: From Prehistory to History, pp. 68-88. RoutledgeCurzon Press: London and New York.

Bhattarcharya, K. 1997. The religions of ancient Cambodia. In H.I. Jessup and T. Zéphir (eds.), Sculpture of Angkor and Ancient Cambodia: Millennium of Glory, p. 34-52. Washington, D.C.: National Gallery of Art.

Boisselier, J. 1966. Le Cambodge. Manuel d' archéologie d' Extreme-Orient; Premiere parte, Asie du Sud-Est, Vol. 1. Paris: A. et J. Picard.

Boisselier, J. 1989. Trends in Khmer Art. Ed. N. Eilenberg. Translated By N. Eilenberg and Melvin Elliott. Ithaca, New York: Studies on Southeast Asia, Southeast Asia Program, Cornell University.

Coedès, G. 1968. The Indianized States of Southeast Asia. Ed. W. F. Vella. Translated by S. B. Cowing. Honolulu: University of Hawaii Press.

Dalsheimer, N. 2001. Les collections du Musée national de Phnom Penh: l'art du Cambodge ancient. Paris: Ecole Française d'Extrême-Orient and Magellan \& Cie.

Dalsheimer, N., and P.-Y. Manguin. 1998. Visnu mitrés et réseaux marchands en Asie du Sud-est: Nouvelles données archéologiques sur le Ier millénaire apr. J.-c. Bulletin de l'École Française d'Extrême Orient 85:87-124.

Dao, L.C. 1993. On the dating of the Oc Eo Culture (from results of C14 analyses). Vietnam Social Sciences 37(3):114-119.

Dowling, N.H. 1999 A new date for the Phnom Da images and its implications for early Cambodia. Asian Perspectives 38(1):51-61.

Feathers, J. K. 1997. Luminescence dating of bricks from Cambodian temple sites. Ms. on file, Department of Anthropology, University of Hawaii.

Gaur, A.S., Sundaresh, Tripati, S. 2005. Underwater explorations of a Sangam period (300 BC-AD 400) port town at Poompuhar, east coast of India. In Revealing India's Past: Recent Trends in Art and Archaeology (Prof. Ajay Mitra Shastri commemoration volume), pp. 33-43. New Delhi: Aryan Books.

Groslier, G. 1935. Ankor Borei. Bulletin de l'École Française d'Extrême-Orient 35:491.

Haertel, H. 1993. Excavations at Sonkh. Berlin: Dietrich Reimer Verlag.

Hall, K. 1982. The Indianization of Funan: An economic history of Southeast Asia's first state. Journal of Southeast Asian Studies 13:81-106.

Hall, K. 1992. Economic history of early Southeast Asia. In K. Taylor (ed.), The Cambridge History of Southeast Asia, Vol. One, pp. 183-275. Cambridge: Cambridge University Press.

Higham, C. F. W. 2002. Early Cultures of Mainland Southeast Asia. Bangkok, Thailand: River Books.

Indrawooth, P. 2004. The archaeology of the Early Buddhist kingdoms of Thailand. In I. Glover and P. Bellwood (eds), Southeast Asia: From Prehistory to History, pp. 120-148. New York: RoutledgeCurzon.

Kramrisch, S. 1976. The Hindu Temple. Delhi, Varanasi, Patna, India: Motilal Banarsidass.

Krishna Murthy, K. 1983. Origin of Brahmanical apsidal shrines in Andhra. In KV Raman, KG, Krishnan, N. S.Ramaswami, N. Karashima, AVN. Murth, P. Shan- 
mugam, and S. Srinivasan (eds.), Srinidhih: Perspectives in Indian Archaeology, Art and Culture, pp. 65-66. Madras: New Era Publications.

Kulke, H. 1990. Indian colonies, Indianization or cultural convergence? Reflections on the changing image of India's role in South-East Asia. In H.S. Nordholt (ed.), Onderzoek in Zuidoost-Azie: Agenda's voor de Jaren Negentig, pp. 8-32. Leiden: Rijksuniversiteit te Leiden, Vakgroep Talen en Culturen van Zuidoost-Azie en Oceanie.

Lavy, P. A. 2003. As in heaven, so on earth: The politics of Visnu, Śiva and Harihara images in preangkorian Khmer civilization. Journal of Southeast Asian Studies 34(1):2139.

Lunet de Lajonquière, E. E. 1901. Atlas archéologique de l'Indo-Chine: Monuments du Champa et du Cambodge. Paris: Publications de l'École Française d'Extrême Orient.

Lunet de Lajonquière, E. E. 1902-1911. Inventaire descriptif des monuments du Cambodge. 3 vols. Publications de l'École Française d'Extrême Orient vol. IV, VIII-IX, Paris.

Luong, N. 1995. Buddhist statue of Nen Chua and Nen Chua style of Buddhapad statues. Khảo co họ 2:51-59. (In Vietnamese).

Luong, N. 2000. Ancient culture of Mekong River delta. Vietnam Social Sciences 3(77): 61-70.

Mabbett, I. 1997. The "Indianization" of mainland Southeast Asia: A reappraisal. In N. Eilenberg, M.C. Subhadradis Diskul, and R.L. Brown (eds.), Living a Life in Accord with Dhamma: Papers in Honor of Professor Jean Boisselier on his Eightieth Birthday, pp. 342-55. Bangkok: Silpakorn University.

Malleret, L. 1959. L'Archéologie du Delta du Mékong, Part 1. L'Exploration Archéologique et Les Fouilles d'Oc-Èo. Publication de l'École Française d'Extrême-Orient, Paris.

Malleret, L. 1960. L'Archéologie du Delta du Mékong, Part 2. La Civilisation Matérielle d'Oc-Èo. 2 vols. Publication de l'École Française d'Extrême-Orient, Paris.

Malleret, L. 1962. L'Archéologie du Delta du Mékong, Part 3. La Culture du Fou-Nan. 2 vols. Publication de l'École Française d'Extrême-Orient, Paris.

Manguin, P.-Y. and Vo Si Khai 2000. Excavations at the Ba The/Oc Eo Complex (Viet Nam): A preliminary report on the 1998 campaign. In W. Lobo and S. Reimann (eds.), Southeast Asian Archaeology 1998, pp. 107-121. Hull: University of Hull, Centre for South-East Asian Studies.

Michell, George. 1988. The Hindu Temple: An Introduction to Its Meaning and Forms. Chicago: University Of Chicago Press.

Moore, E. 1988. Moated Sites in Early Northeast Thailand. British Archaeological Reports 400. Oxford: BAR.

Moore, E. 1992. Water enclosed sites: links between Ban Takhong, Northeast Thailand and Cambodia. In J. Rigg (ed.), The Gift of Water: Water Management, Cosmology and the State in South East Asia, pp. 26-46. London: School of Oriental and African Studies.

Moore, E. 2004. Interpreting Pyu material culture: Royal chronologies and finger-marked bricks. Myanmar Historical Research Journal 13:1-57.

Myint Aung. 1970. The excavations at Halin. Journal of the Burma Research Society 53(2):55-64.
Parmentier, H. 1932. L'art présumé du Fou-Nan. Bulletin de l'Ecole Française d'Extrême Orient 32:183-189.

Parmentier, H. 1931. History of Khmer Architecture. Eastern Art 3:141-179.

Parmentier, H. 1927. L'Art Khmer Primitif. Paris: Librairie National d'Art et d'Histoire.

Pelliot, P. 1903. Le Fou-nan. Bulletin de l'École Française d'Extrême Orient 3: 248-303.

Ray, H. P. 1997. The emergence of urban centres in Bengal: Implications for the late prehistory of Southeast Asia. Bulletin of the indo-Pacific Prehistory Association 16:43-48.

Ray, H. P. 2004a. The apsidal shrine origins, cultic affiliation, patronage. World Archaeology 36(3):343-359.

Ray, H. P. 2004b. The archaeology of sacred space: Introduction. In H. P. Ray and C. M. Sinopoli (eds.), Archaeology as History in Early South Asia, pp. 350-375. New Delhi: Indian Council of Historical Research and Aryan Books International.

Ray, H. P. 2005. The Axial Age in South Asia: The archaeology of Buddhism. In M. Stark (ed.), Archaeology of Asia, pp. 303-323. Malden, MA: Blackwell Publishers.

Sanderson, D.C.W. and R.G. Bingham. 2004a. Luminescence dating of bricks from Angkor Borei, Cambodia. Report on file, Scottish Universities Environmental Research Centre, East Kilbride, Scotland.

Sanderson, D.C.W. and R.G. Bingham. 2004b. Luminescence dating of brick monuments in the vicinity of Angkor Borei, Cambodia. Report on file, Scottish Universities Environmental Research Centre, East Kilbride, Scotland.

Sarma, I. K. 1983. Brick temples of Western Gangas. In KV Raman, KG, Krishnan, N. S.Ramaswami, N. Karashima, AVN. Murth, P. Shanmugam, and S. Srinivasan (eds.), Srinidhih: Perspectives in Indian Archaeology, Art and Culture, pp. 67-83. Madras: New Era Publications.

Smith, M. L. 1999. "Indianization" from the Indian point of view: Trade and cultural contacts with Southeast Asia in the early first millennium C.E. Journal of the Economic and Social History of the Orient 42(1):1-26.

Southworth, W. A. 2004. The Coastal States of Champa. In I. Glover and P. Bellwood (eds), Southeast Asia: From Prehistory to History, pp. 209-233. New York: RoutledgeCurzon.

Stark, M.T. 1998. The transition to history in the Mekong delta: a view from Cambodia. International Journal of Historical Archaeology 2(3):175-204.

Stark, M.T. 2003. Angkor Borei and the archaeology of Cambodia's Mekong Delta. In J.C.M. Khoo (ed.), Art \& Archaeology of Fu Nan: Pre-Khmer Kingdom of the Lower Mekong Valley, pp. 87-106. Bangkok: Orchid Books.

Stark, M. T. and Bong S. 2001. Recent research on the emergence of early historic states in Cambodia's lower Mekong. Bulletin of the Indo-Pacific Prehistory Association 19: 85-98.

Stark, MT, Griffin, P. B, Chuch, P, Ledgerwood, J. Dega, M, Mortland, C, Dowling, N. Bayman, J. M, Bong, S., Tea V., Chhan C., Latinis, D. K. 1999. Results of the 1995-1996 field investigations at Angkor Borei, Cambodia. Asian Perspectives 38: 1:7-36.

Stuiver M., P.J. Reimer, E. Bard, J.W. Beck, G.S. Burr, K.A. Hughen, B. Kromer, G. McCormac, J. van der Plicht and 
M. Spurk. 1998. INTCAL98 Radiocarbon age calibration, 24000-0 cal BP. Radiocarbon 40(3) 1041-1083.

Trinh, Thi Hoà. 1996. Réflexions sur les vestiges de la culture d'Oc Eo. Études Vietnamiennes 50(120):109-123.

Vickery, M. 1998. Society, Economics, and Politics in PreAngkor Cambodia: The 7th-8th Centuries. Tokyo: The Centre for East Asian Cultural Studies for UNESCO, The Toyo Bunko.

Vo Si Khai 1998. Plans architecturaux des ancients monuments du Delta du Mékong du 1er au 10e siècles AD. In P.-Y. Manguin (ed.), Southeast Asian Archaeology 1994, Volume 1, pp. 207-214. Hull, England: Centre for Southeast Asian Studies, University of Hull.
Vo Si Khai. 2003. The Kingdom of Fu Nan and the culture of Oc Eo. In J. C. M. Khoo (ed.), Art \& Archaeology of Fu Nan: Pre-Khmer Kingdom of the Lower Mekong Valley, pp. 35-86. Bangkok: Orchid Press.

Wheatley, P. 1983. Nagara and Commandery: Origins of the Southeast Asian Urban Traditions. Research Paper Nos. 207-208. Chicago: Department of Geography, University of Chicago. 